\title{
Corporate-startup Co-creation for Increased Innovation and Societal Change
}

\author{
Annika Steiber \\ Management Department, Menlo College, Atherton, California, USA \\ Annika.steiber@menlo.edu \\ Sverker Alänge \\ Department of Technology Management and Economics, Chalmers \\ University of Technology, Gothenburg, Sweden \\ sverker.alange@gmail.com
}

\begin{abstract}
The emphasis on corporate-startup collaboration has reached a new level in the context of digital transformation of most industries. Co-creation, as one non-equity based model for corporate-startup collaboration is increasingly getting attention among corporations and startups, but also among local governments. However, even if companies, governments, and startups invest in this approach for innovation and societal change, the concept is under-researched. The purpose of this paper is to further examine corporate-startup co-creation by conducting a systematic literature review, as well as present a real case 'FirstBuild'. The findings were that co-creation as a corporatestartup collaboration model increases in attention. However, there is currently a large knowledge gap in previous research in regards to this phenomenon and more research on corporate-startup co-creation is needed, specifically in regards to metrics and its effects on corporate innovation, startups' growth, and society.
\end{abstract}

\section{Keywords}

Co-Creation - Innovation - Societal change - FirstBuild - Startup collaboration - GE 


\title{
Arabic
}

الإنشاء المشترك بين الشركات والشركات الناشئة لدعم الابتكار والتغييرات المجتمعية

\author{
Annika Steiber, Sverker Alänge
}

وصل التركيز على التعاون بين الشركات والشركات الناشئة إلى مستوى جديد في سياق التحول الرقمي لمعظم الصناعات .ولكن في.

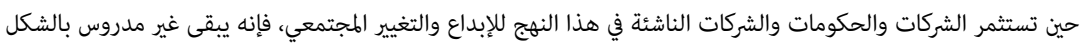

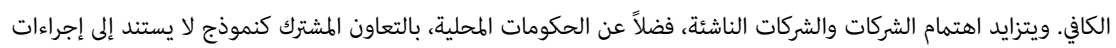

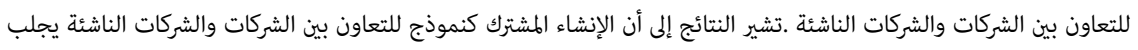

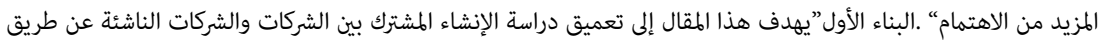

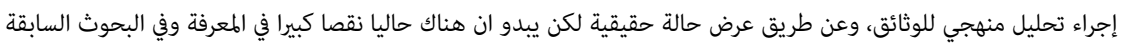

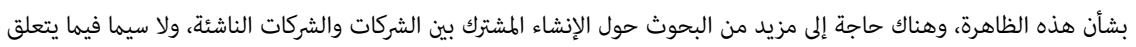

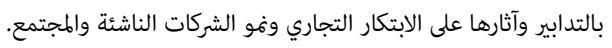

الكلمات المفتاح

المشاركة، الابتكار،التغييرات المجتمعية ، البناء الأول ، التعاون مع الشركات الناشئة، المؤسسات الكبرى

\section{Chinese}

\section{大企业一初创企业共同创造以增强创新和社会变革}

\author{
Annika Steiber, Sverker Alänge
}

\section{摘要}

在大多数产业进行数字化转型的背景下, 对大企业-初创企业的合作的重视 达到了新的水平。共创, 作为一种基于非股权的大企业初创企业合作模 式, 正越来越受到大企业和初创企业以及地方政府的矢注。但是, 即使公 司、政府和初创企业都以这种方式为创新和社会变革投资, 但对这一概念 的研究仍然不足。本文旨在通过进行系统的文献综述来进一步研究大企业 与初创公司的共同创造, 并展示一个真实案例 “FirstBuild”。研究结果表 明, 共同创造作为大企业-初创企业之间的合作模式受到越来越多的矢注。 然而, 目前在以往的研究中, 矢于这种现象的知识差距很大, 需要对大企 
业-初创剬司的共同创造进行更多的研究, 特别是在测量指标及其对大企业 创新、初创企业成长和社会的影响。

\title{
关键字
}

共同创造, 创新, 社会变革, FirstBuild, 初创企业合作, GE

\section{French}

\section{Co-création d'entreprise-startup pour une innovation accrue et un changement sociétal}

\author{
Annika Steiber, Sverker Alänge
}

\section{Résumé}

L'accent mis sur la collaboration entre les entreprises et les startups a atteint un nouveau niveau dans le contexte de transformation numérique de la plupart des industries. La co-création, un modèle non égalitaire de collaboration entre les entreprises et les startups, retient de plus en plus l'attention au sein des entreprises et des startups, mais aussi au sein des gouvernements locaux. Cependant, même si les entreprises, les gouvernements et les startups investissent dans cette approche pour l'innovation et le changement sociétal, le concept n'est pas assez étudié. Cet article vise à examiner plus en détail la co-création d'entreprise-startup par une revue de la littérature et une présentation d'une étude de cas de «FirstBuild». Les résultats ont montré que la cocréation en tant que modèle de collaboration entreprise-startup capte de plus en plus l'attention. Cependant, il existe actuellement un grand manque de connaissances dans les recherches antérieures concernant ce phénomène; et, davantage d'études sur la cocréation d'entreprises et de startups sont nécessaires, plus spécifiquement en ce qui concernent sa mesure et ses effets sur linnovation des entreprises, la croissance des startups et la société.

\section{Mots-clés}

Co-création - innovation - changement sociétal - FirstBuild - collaboration de Startup - GE 


\title{
Portuguese
}

\section{Co-criação de startups corporativas para maior inovação e mudança social}

\author{
Annika Steiber, Sverker Alänge
}

\section{Resumo}

A ênfase na colaboração entre empresas e startups atingiu um novo nível no contexto de transformação digital da maioria das indústrias. A cocriação, como um modelo não baseado em ações para colaboração entre empresas e startups, está cada vez mais chamando a atenção entre corporações e startups, mas também entre governos locais. No entanto, mesmo que empresas, governos e startups invistam nessa abordagem para inovação e mudança social, o conceito é pouco pesquisado. O objetivo deste artigo é examinar mais detalhadamente a co-criação de empresas, realizando uma revisão sistemática da literatura, além de apresentar um caso real 'FirstBuild'. As conclusões foram de que a cocriação como modelo de colaboração entre empresas e startups aumenta a atenção. No entanto, atualmente há uma grande lacuna de conhecimento em pesquisas anteriores sobre esse fenômeno e mais pesquisas sobre co-criação de empresas são necessárias, especificamente em relação às métricas e seus efeitos na inovação corporativa, no crescimento de startups e na sociedade.

\section{Palavras-chave}

Co-criação - inovação - mudança social - FirstBuild - colaboração de startups - GE 


\title{
Russian
}

\section{Сотворчество корпораций и стартапов в контексте усиления инноваций и социальных изменений}

\author{
Анника Штейбер, Сверкер Аланж
}

\begin{abstract}
Аннотация
Роль сотворчества между корпорациями и стартапами достигло нового уровня в контексте цифровой трансформации в большинстве сфер промышленности. Сотворчество, как одна из непроизводственных моделей коллаборации больших и малых компаний, привлекает все больше внимания со стороны корпораций и стартапов, а также среди локальных органовуправления. Однако, даже среди компаний, правительства и стартапов, реализующих данный подход к развитию инноваций и социальных изменений, он является недостаточно изученным. Целью настоящей работы является дальнейшее изучение сотворчества между корпорациями и стартапами путем проведения систематизированного обзора литературы, а также презентация кейса «FirstBuild». Основные выводы заключаются в том, что сотворчество в качестве модели коллаборации корпорации и стартапа укрепляет свою значимость. Однако, в настоящее время наблюдается значительный дефицит информации в предшествующих исследованиях, касающихся данного феномена, поэтому необходимо продолжить дальнейшие изыскания, посвященные сотворчеству между корпорациями и стартапами, особенно в контексте количественной оценки и их влияния на корпоративные инновации, развитие стартапов и общество.
\end{abstract}

\section{Ключевые слова}

Сотворчество - Инновации - Социальные изменения - кейс «FirstBuild»- Коллаборация стартапов - GE 


\title{
Spanish
}

\section{Co-creación corporativa-startup para mayor innovación y cambio social}

\author{
Annika Steiber, Sverker Alänge
}

\begin{abstract}
Resumen
El énfasis en la colaboración entre empresas y startups ha alcanzado un nuevo nivel en el contexto de transformación digital de la mayoría de las industrias. La co-creación, como un modelo no basado en la equidad para la colaboración entre empresas y startups, está recibiendo cada vez más atención entre corporaciones y startups, pero también entre gobiernos locales. Sin embargo, incluso si las empresas, los gobiernos y las nuevas empresas invierten en este enfoque para la innovación y el cambio social, el concepto está poco investigado. El propósito de este documento es examinar más a fondo la creación conjunta de empresas y emprendimientos mediante una revisión sistemática de la literatura, así como presentar un caso real "FirstBuild". Los hallazgos fueron que la co-creación como modelo de colaboración entre empresas y startups aumenta su atención. Sin embargo, actualmente existe una gran brecha de conocimiento en investigaciones previas con respecto a este fenómeno y se necesita más investigación sobre la co-creación corporativa-startup, específicamente en lo que respecta a las métricas y sus efectos sobre la innovación corporativa, el crecimiento de las startups y la sociedad.
\end{abstract}

\section{Palabras clave}

Co-creación - innovación - cambio social - FirstBuild - Startup colaboración - GE

\section{Introduction}

Major drivers such as technological development, globalization of markets and knowledge production, combined with climate change and sustainability requirements, create a tremendous pressure on incumbents to radically change the way they are organizing their innovation processes, if they at all will have a chance of surviving and prospering (March 1991; Christensen and Overdorf 
200o; Lee et al. 2012; Steiber and Alänge 2015). In many cases corporate-startup collaboration is a way to speed up innovation for the corporation (Alänge and Steiber 2018), but it can also be a way to take part in the construction of totally new entrepreneurial ecosystems (Drori and Wright 2018) and to learn from these ecosystems how to best adjust the large firm's business- and operational model.

The transformational changes of most industries are therefore increasing the emphasis on startups' role in corporate innovation. There are many different models, both equity based and non-equity based for how corporate-startup collaboration could be designed and executed (Weiblen and Chesbrough, 2015; Alänge and Steiber, 2018). However, non-equity forms of collaboration to source innovation from startups increasingly gets traction among large corporations (Weiblen and Chesbrough 2015) and from local governments, as this is one way to strengthen strategic industries for the country and to create new job opportunities. For the startups (that might be located at local universities, at government-funded incubators, or in the industry), this strategic avenue is also of interest as it could be a way for them to overcome innovation diffusion challenges (Autio et al. 2018) without giving up equity.

Co-creation, as one type of non-equity collaboration models can generate a multitude of organizational advantages, including improved innovation performance (Markovic and Bagherzadeh 2018). Co-creation between large and small firms can also speed up knowledge production, innovation and therefore the economy of whole industries in a country, which is of great interest for local policy makers.

However, our knowledge concerning co-creation models for increased innovation and societal change is not well researched, "Despite growing interest in co-creation, scholars call for more work in this important area of research" (Frow et al. 2015: 463).

The purpose of this article is therefore to further examine models for cocreation between large and small firms. Co-creation is in this article viewed as a particular form of open innovation and as a purposive process, distinct from other concepts such as corporate accelerator, corporate incubator, co-location, platforms, and startup programs that all can include activities of co-creation in their processes for corporate-startup collaboration.

The sections below start with methodology and a theoretical framework in the form of general models for corporate-startup collaborations (both equity and non-equity forms). Next come a literature review on co-creation for increased innovation and what is known about co-creation as a non-equity corporate-startup collaboration model. This chapter will be followed by a discussion, conclusions and implications. 
The authors' research began in 2014 with an initial search for approaches for large firms to accelerate innovation by using an open innovation approach focused on collaboration with startups. Open innovation is here defined according to Chesbrough (2003):

Open Innovation is a paradigm that assumes that firms can and should use external ideas as well as internal ideas, and internal and external paths to market, as the firms look to advance their technology.

An abductive approach (Dubois and Gadde 2002) was followed, in which the authors' empirical research began with identifying and contacting large companies that use various models of corporate-startup collaborations. Through interviews with 30 large companies across Europe and the US, several different corporate-startup collaboration models were identified (Steiber and Alänge, 2020 ). In addition, a follow-up study was initiated in 2017 , involving initially seven, and later in 2019, nine Swedish multinational corporations. Six of the nine were part of the authors' earlier research between 2014 and 2017, and three were new. The purpose of this follow-up study was to deepen the knowledge and further examine and understand benefits and challenges with each identified model for corporate-startup collaboration.

Alänge et al. (Steiber and Alänge, 2020) identified eight different corporatestartup collaboration models currently applied by large firms in the West. Four of these are equity-based models, and four are non-equity based. In several of the non-equity based cases, the local government had contributed with funding. Therefore, in those non-equity models, three rather than two stakeholders exist, the large firm, the startups, and the government.

This article will focus on one of the non-equity based models, namely "coCreation". After selecting co-Creation as the scope for the study, a systematic literature review was conducted in May to August 2019 on "co-creation" for innovation and co-creation as a corporate-startup collaboration model specifically. As was mentioned earlier, several stakeholders, such as the corporation, the startup, and the government, could be involved in funding the co-creation model, why both business and social objectives could co-exist.

For the literature review the methodological guidelines of Webster and Watson (2002) were followed. The research areas were defined as: co-creation, co-creation and startup collaboration, as well as co-creation and metric, cocreation and evaluation, co-creation and performance, co-creation and effect, and co-creation and impact. The goal was to conduct a review of the scientific 
literature from 2009 to 2019 in order to identify findings more relevant for today's economy. After defining the research scope, keywords such as: "cocreation", "co-create", "co-design", "co-develop", "co-produce", and "co-innovate", were used.

Academic literature matching any of these search strings were searched for in the databases:

E BSCO and Business Source Complete, ABI Proquest and Proquest Dissertations and thesis, JSTOR and Business, ScienceDirect, as well as Google Scholars. The databases were selected as they index most significant journals and conferences, as well as dissertations in the management domain. As a first step, titles and abstracts were manually screened. Articles rated A by the authors were articles that are literature reviews on co-creation.

Articles focused on specific co-Creation cases were classified as B articles. Finally, articles that were not directly relevant to the purpose of this article were classified as $\mathrm{C}$ articles and excluded. The result arrived at a final of 30 scientific articles, which were analyzed in detail following Webster and Watson methodology (2002).

The results from the literature review were then discussed in relation to one of the case studies of 'co-creation' that was part of the authors' empirical study; GE Appliances' FirstBuild (Alänge and Steiber 2018; Alänge and Steiber, 2019). The data for this case come from interviews with one of the founders of FirstBuild, supplemented by secondary data, including from the FirstBuild homepage and communication platform and a recent article that detailed the development of FirstBuild and its performance metrics (Hagel et al. 2018).

\section{Theoretical Context: Corporate-startup Collaboration Models}

The Internet, cheap information processing and artificial intelligence, as well as cloud technology and Internet of Things (IoT), have not only shortened product life cycles in many industries but forced companies to increase their focus on both business- and operational model innovations (Ghosh et al. 2017). At the same time, IT and the Internet have also enabled greater collaboration with various partners outside the firm, which has led large firms to test new collaborative models with startups.

Chesbrough (2003) developed the open innovation concept from observations of inbound and outbound streams of technology at large firms. The fast technology development in most industries is now increasing the emphasis on startups' role in corporate innovation, as the strength of small technology startups is their ability to develop not only new product and process innovations 
rapidly and test them on 'early adopters' (Rogers 1995), but also to develop entirely new business models. For large firms, technology startups can also allow the large firm to be part of the construction of totally new entrepreneurial ecosystems (Drori and Wright 2018), otherwise maybe not available for the large firms. The main weakness with startups is their limited ability to scale up for high-volume operations (Autio et al. 2018). Large firms typically show the opposite areas of strengths and weaknesses. This has led some authors to suggest cooperation in which the large and the small firm play interactive and complementary roles (Rothwell and Dodgson 1991; Prashantham and Birkinshaw 2008).

Weiblen and Chesborough (2015: 67) reported: "During the last few years... corporate efforts to reach out to the startup ecosystem seem to be on the increase. In its quest for speed and innovation, the tech industry, in particular has produced a variety of ways of engaging with startups."

The literature review and empirical research conducted by Alänge and Steiber (2018) delved deeply into various corporate strategies for corporatestartup collaboration for increased corporate innovation. Eight different models were identified and presented in a two dimensions framework in Alänge et al. (Steiber and Alänge, 2020). The dimensions in the framework are; the direction of the innovation process ("outside-in" or "inside-out"), and if the large firm take equity or not in the startup. The eight different models are briefly described below.

\section{Corporate Venturing and Acquisition}

One approach is corporate venturing, investing in external startups of strategic interest, and some of these may be acquired at some point. The other approach in which the large firm take equity in the startup is acquisition, a common way of obtaining assets developed elsewhere - including technology, talent, competencies, and/or patent portfolios (Steiber and Alänge, 2020). Acquisitions and corporate venturing are the oldest models of the eight. Venture activities first appeared in the 196os and has mirrored the industry as a whole (Gompers and Lerner 2000).

\section{$5 \quad$ Internal Corporate Incubator and Corporate Accelerator}

Large firms have realized the need for rapid learning. The work of Steve Blank and Eric Ries (Blank 2005; Ries 2011) introduced the "lean startup" methodology, 
which has influenced the design of two other collaboration models: internal corporate incubation, where internal ideas may lead to spinout companies, which put internal assets to use and can also potentially be reacquired later, and internal accelerator programs, an intensive, shorter program in which cohorts of (here internal) idea providers are coached to take their ideas further (Cohen and Hochberg 2014). Both are here viewed as equity-based models for collaboration with a focus inside-out (Steiber and Alänge, 2020). ${ }^{1}$

\section{$6 \quad$ Platform and Corporate Startup Programs}

By platforms it is meant a large firm's proprietary platform, e.g., Android or iOS. The "Platform model" is an Inside-out approach in which the larger firm invites complementary external startup innovation to advance existing corporate innovation (the platform), but also to strengthen the large firm's ecosystem (Steiber and Alänge, 2020).

The primary purpose of setting up a Corporate Startup Program such as e.g. Google for Startups, is for the large firm to support entrepreneurs with access to the large firm's products, services, or other assets and thereby sustaining or even expanding the ecosystem around the large firm's products and services. The 'platform' and the 'corporate startup program' are both examples on nonequity collaboration models and are rather new concepts from the 2ooos. For example, NTT DoCoMo's i-mode platform was launched in 1999 and both Apple App Store and Google's Android platform were launched in 2008. Google for Startups was launched in 2018 (formerly Google for Entrepreneurs launched in 2011).

Co-creation and Co-location

Finally, Co-creation and co-location as models for corporate-startup collaboration are both non-equity models focused on taking external innovation inbound to the benefit innovation processes in large corporations. Co-creation is a management initiative, or form of economic strategy, that brings different parties together (for instance, a company and a group of customers), in order to jointly produce a mutually valued outcome (Normann and Ramirez 1993; Wikström 1996; Prahalad and Ramaswamy 2004). Prahalad and Ramaswamy (2000) initially primarily focused on the co-creation benefits of the more connected and empowered consumers and it was not until 2010, Ramaswamy and Gouillart (2010) expands the concept to more stakeholders. 
Business co-location is the placement of several entities in a single location. Co-location as a concept has been used in many industries, e.g. fast food stores, airports, data centers and more. In the context of co-location of tech startups close to a host corporation, co-location is a rather new phenomenon. Colocation initiatives for startups commonly offer co-working space for a low rent, some business services, but also in several cases access to the large firm's equipment and lead researchers (Steiber and Alänge, 2020).

\section{Literature Review on Co-creation}

Co-creation, as described above, is one of several non-equity models for corporate-startup collaboration. The concept was, however, initiated in a service context, as a service is in some way always recreated in the moment of production when the supplier meets the customer.

Normann (2001) outlined and described co-creation processes where the user has an important role. As was mentioned earlier also Prahalad and Ramaswamy (2000) initially focused on the benefits of the more connected and empowered consumers. However, in the last decade; "the frame of reference has been extended to an emerging business and innovation paradigm that leads to the need of "changing the very nature of engagement and relationship between the institution of management and its employees, and between them and co-creators of value - customers, stakeholders, partners and other employees" (Ramaswamy 2009)." In fact, co-creation is an essential force in any "dynamic innovation ecosystem because a continual realignment of synergistic relationships of people, knowledge, and resources is required for growth of the system and responsiveness to changing internal and external forces..." (Huhtamäki et al. 2011). The platform economy address opportunities for corporate-startup co-creation through digital platforms (Korhonen et al. 2017).

In fact, the co-creation concept has increasingly been used for various innovation processes, including inputs from lead-users, makers, and smaller firms. Vargo et al. (2008) argue that the service-dominant (SD) logic provides a perspective that can be useful in value co-creation in service systems, and according to Hughes (2014) also among triple helix stakeholders, which include stakeholders such as government, universities and industry.

In addition to an expansion of actors that could be of interest for a corporation to co-create together with, co-creation is also found in the different steps of a value chain. For example, there has been an increasing interest and several articles about specific ways to co-create during the idea phase (Hughes 2014). Crowdsourcing of ideas is increasingly practiced in the industry, either with 
participation from within organizations or with participation from designated communities, or open for anyone who likes to contribute with an idea. There are basically two approaches to crowdsourcing ideas, either to present a clearly defined problem that needs a solution or to present challenge areas in search of new innovative approaches, i.e. a broader way of inviting to idea generation (Alänge and Steiber 2018). Sometimes co-creation includes hackathons where idea providers also have the opportunity to go directly into a maker space in order to design and develop (co-design, co-develop) a first simple demonstration prototype within a very short time period, e.g. 48 hours. There are companies specializing in facilitating maker events including both building communities and establishing physical labs where makers for a very limited fee can access advanced metal and wood working machinery in order to build functional prototypes (Alänge and Steiber 2019). Mark Hatch, the co-founder of one of the pioneering makerspace organizations, TechShop commented that: "Average people pay a small fee for access to advanced tools ... All they have to bring is their creativity and some positive energy. Prototypes of new products that would have cost $\$ 100.000$ in the past have been made ... for $\$ 1.000$... giving rise to successful new business ventures" (Hatch 2013). Through the internet, the Maker Movement has expanded to global reach and today companies organize their innovation processes benefitting from input from makers.

Co-creation in the form of co-development was, however, initially linked to the development with lead users, e.g. technically advanced users of scientific instruments (Von Hippel 1976). Later on, Von Hippel (2005) and others broadened their focus to other advanced end-users, but also actors such as startups, e.g. through digital platforms. The co-creation between corporations and startups could, however be challenging as Islam et al. (2017: 1029-1030) point out: "Currently, collaboration between incumbent firms and start-ups is enjoying a resurgence through the pervasive phenomenon of digitalization", and that "researchers have found that, when the two work together, it is a balancing act, as it is a cooperation and competition at the same time". Co-production in the sense of involving customers in the production of goods and services have been quite well researched and Bendapudi and Leone (2003) state: "customer participation in the production of goods and services appears to be growing". In regards to corporate-startup co-production, some interesting research can be found, e.g. Fochler (2016) pointed out that biotechnology researchers found startups to be centers of knowledge production, and Rise (2002) investigated the co-production between corporate incubators and startups joining the incubator.

However, even if we did find some research on co-creation between corporations and startups, co-creation models based on corporate-startup 
collaboration is not well researched: "Despite growing interest in co-creation, scholars call for more work in this important area of research" (Frow et al. 2015: 463). Further, Valkokari et al. (2017) point at the importance of "orchestrating innovation ecosystems" and emphasize that all companies need ecosystem competence that is defined as "ability to manage dynamic strategic interactions related to innovation". Finally, not only research on how to design and operate co-creation efforts between corporations and startups, but also research on how to measure those initiatives' business and societal effects is lacking. There are in fact very few articles that focus on metrics and evaluation of cocreation efforts (Pei 2017). Most articles identified in the literature review were focused on evaluation/performance/impact through co-creation with customers and consumers (e.g. Fuller et al. 2009; Fuller 2010; Piller and Ihl 2013; Nishikawa et al. 2013; Karpen et al. 2015;) or between supplier and customer (Enz and Lambert, 2012; Vesalainen et al. 2017). Some recent articles focus on evaluation of co-creation in networked collaboration platforms (e.g. Maciuline and Skarzauskiene 2016). Some articles focus on identifying factors influencing the success or antecedents of co-creation, e.g. Frow et al. (2015), who argue that managers can use their model to identify opportunities for co-creation. Further, based on 30 interviews concerning enabling factors for collaboration, Islam et al. (2017: 1038) found that "the enabling factor most frequently stated by experts from incumbent firms was; 'Perceived (increased) Innovation Performance'. Referring to extant research, Islam et al. (2017:1039) added that 'the results of the interviews illustrate that none of the collaborations observed had a clear definition and expected output, even though, according to Weiblen and Chesbrough (2015), this is essential in a collaboration process." Hence, to date, there is relatively little empirical work addressing co-creation from a performance perspective."

\section{Firstbuild: A Case Study}

FirstBuild was created in 2014 as an independent unit but wholly owned subsidiary of GE Appliances (GEA). The launch of the new venture was to allow for product and business model development in an open innovation environment that is not restricted by the incumbent's culture and established way of organizing. However, GEA's local partners such as the University of Louisville, the city, and the state government also had objectives with the launch, such as to provide local inventors and students a place to test their ideas in real time.

GEA had earlier been trained in, and tried the lean startup methodology with the creation of MVP (Minimum Viable Products) and rapid market tests 
(Ries 2011; Blank 2013) but found it difficult to implement the new methodology within the regular GEA organization. FirstBuild, on the other hand, that takes its inspiration from lean startup and startup companies' nimbleness, has the freedom of running the company as a small startup. It can develop small initial batches of new product concepts, finding new ways to reach customers and obtaining real-time feedback from them, including how much they would be willing to pay for the new product. While GEA was acquired by the Haier Group in 2016, FirstBuild remains a subsidiary and independent innovation unit for GEA and is supported by the Haier top management (Alänge and Steiber 2019).

FirstBuilt presents itself at the homepage as "a global co-creation community that harnesses the brainpower of the maker movement to change the way major home appliances are conceived, designed and manufactured" (see FirstBuild homepage).

Through an online forum and a physical state-of-the-art microfactory on the campus of the University of Louisville, FirstBuild speeds products from mind to market and enables customization through small batch production, without the costs and risks of traditional mass manufacturing. FirstBuild has an internet-based communication platform to enable crowdsourcing of ideas and crowd-decision-making concerning the future of ideas and product prototypes being developed. This platform was designed based on support from Local

Motors, which had a similar platform in use at the time FirstBuild was conceived (Alänge and Steiber 2019). The FirstBuild mission is to "Invent a new world of home appliances by creating a socially-engaged community of home enthusiasts, designers, engineers, and makers who will share ideas, try them out, and build real products to improve your life." The goal is to co-create new product and business model innovations with startups and individual makers from the community as contributors: "Our co-create platform was made for makers. It is the place where all of our community's ideas come together." (FirstBuild homepage).

From a societal perspective FirstBuild points at that "Everything we do will benefit our community of engineers, designers, fabricators and home enthusiasts. We will empower the individual maker by facilitating innovation from mind to market through a collaborative design-build-sell process." FirstBuild also emphasizes their goal "to build a sustainable co-creation community through recognition and attribution while advancing the environment, continuously improving the safety and well-being of diverse societies." and that "We will create value by rapidly delivering better products that improve the lives of our community and our customers." (FirstBuild homepage). The microfactory is located in direct vicinity to the University of Louisville, and is open 
for interaction and contributions from faculty and students, who also are part of FirstBuild's community. Recently, FirstBuild has been launched in two new locations, in China and India.

The starting point for FirstBuild was a frustration inside the R\&D unit of GE Appliances over the fact that the time to market was very long going through the large corporation's "R\&D to market process". Thus, when FirstBuild was started in 2014 the key measurements of success to be used in the annual review were "How can we be innovative? and "How can we work faster at innovation cycle, and shorten time to market? and "How can you get products to market faster?" In the parent company the average time from idea to market was 4 years and FirstBuild set an ambitious goal to reduce this time to 4 months, which was reached in its 3 rd year of operation, in 2016. The objective was also to bring better products to the market faster, i.e. new and innovative products that "the customer wants, when they want it". To reach the goal of better products to the market faster, First Build needed to increase the number of ideas and products that they receive feedback on from customers.

According to Hagel et al. (2018), FirstBuild tracked two sets of metrics - one focused on financial results for the parent company, the other showing what FirstBuild employees believed mattered most. These metrics included: "how fast the FirstBuild community was growing, what the engagement levels were, and the quality of products under development (measured by the response to products, such as number of preorders and time to funding goal on the platform, along with social enthusiasm of buyers of the product). These were important metrics, albeit numbers without an immediate, tangible financial result tied to them" and they continued "The community's size, engagement, and the number of products and prototypes released are important indicators that get past simply tallying the revenues from the group's successful products. They sacrifice some short-term results, continuing to push boundaries with new product types and focus on reframing risks so that they can act to learn rather than play safe to avoid failure" (Hagel et al. 2018: 9).

FirstBuild does not wait for traditional market data to make decisions, instead the real-time customer reactions to new ideas/products that FirstBuild obtains through its on-line platform become decisive also for if a product will be put on the market or not (e.g. the number of preorders is an indicator for this decision based on what real customers are willing to pay for). Sometimes this has gone contrary to what the FirstBuild employees expected, but in that case the customer data is decisive (such as in the case of a coffee maker that was assumed to be successful in the market - but was stopped after limited preorders). However, even if stopped the FirstBuild culture is to always learn from the failed project and in some cases a shelved product has returned in 
another setting, such as the filtered water pitcher that was stopped as an addon product for customers' current refrigerators but got new life as a standard component in all new refrigerators produced by the mother company. Also crowdfunding data is used for decision-making and products, which are not meeting its funding goal, can also be discontinued. The experience from using Indiegogo, a major commercial crowdfunding organizer that frequently organizes funding for startups, is that FirstBuild's product ideas reach many potential customers and investors that contribute data on the relative attractiveness of the product proposal through their investment decisions.

In early 2019, FirstBuild was launched also in India, once again with the support of local partners such as the state of Telangana and the country's largest makerspace, T-Works. The investment in India is the third, after the launch in Louiseville and in Shanghai. Even if we don't have any actual metrics, other than a very shortened product development cycle, the launch of FirstBuild both in China and India indicates that the effects are positive, for both GEA and for local partners.

\section{Discussion}

Co-creation has historically been discussed mainly from the perspective of corporate-consumer collaboration, e.g. in the production of new goods and services. Over the years, the concept has widened to include suppliers, and new players such as makers. In the last decade, co-creation with new actors in the corporate's innovation system, e.g. startups, is increasingly being recognized. This form of collaboration, between corporations and startups, has been acknowledged to have a high potential for value creation for both firms, based on each actor's different strengths.

However, as was presented in the literature review, co-creation between corporations and startups is a rather new phenomenon and more research is needed in this specific field. One reason for this is that local/regional/national governments seem to primarily fund non-equity models for corporate-startup collaboration. They therefore need to know more about how to design and operate this kind of model for corporate-startup collaboration. In addition, they need to know if this kind of investment pays off in an increased competitiveness of the large and the small firm, as well as creating a stronger local innovation system and new jobs. However, Pei (2017) states that: "One of the most essential problem in value co-creation is the development of comprehensive conceptualizations and measurement scales of value co-creation". For this reason, there is a need of more research on metrics and evaluation of co-creation 
efforts. Types of metrics that could be of extra importance for all three stakeholders, the corporation, the startup and the local government, supporting the co-creation initiative are; Financial metrics (e.g. increase in revenue and/or profitability, increased Rог on new development projects, and more), Market metrics (e.g. new market and/or product segments), Innovation metrics (e.g. metrics on input for innovation (number of patents/resources), number of innovation projects in pipeline due to the collaboration, and metrics on actual innovation output (e.g. number of new product-process-marketingorganization innovations), and finally Network metrics (e.g. the growth of a technology/sector network, the corporation's dynamic importance in this network, the startup's growing importance in this network, and the robustness of the network, as well as the total value creation as part of the GDP, generated by the network).

FirstBuild is one case study on how co-creation between a corporation and startups could be designed and followed up with metrics. While the concept co-creation and presentations of measurements of co-creation performance is kept to a minimum in research literature, FirstBuild has developed structures and means for co-creation with startups and other actors and is tracking its performance in an elaborate way linking to goals and recognized factors that directly influence the outcome. In the FirstBuild case, time to market with new products is crucial. Therefore, the metric: average time from idea to market is important for FirstBuild and has been focused on. In addition to this, the company has two sets of metrics-one focused on the financial end result for the parent company, and the other showing progression, or traction metrics such as; growth of FirstBuild community, engagement level of community, and quality of products under development (with indicators such as amount of preorders and amount of crowdfunding).

FirstBuild's focus has been on shortening the time to market and improving the customer experienced quality of its offerings. However, as the launch of FirstBuild is done in collaboration with the local government, as well as with local makerspace (as in the case of India), or with local universities (as in the case of China), more metrics than the one identified by Hagel et al. (2018) should exist for FirstBuild's other stakeholders.

As could be seen in the case of the launch in Louiseville, other kind of goals come into the forefront, such as support to local inventors and startups, as well as job creation. To a certain extent these goals could overlap, e.g. a large firm strengthening its ecosystem, where startups are important actors, could also contribute to government's goals of creating more jobs. However, the different stakeholders' objectives could also contradict each other such as in one of the authors' case studies in which a firm incubating startups, don't want them to 
grow to quickly in number of personnel due to the increased salary cost, but where local government wants as many jobs as possible created. This points to the importance of clarifying goals and developing measurements from a multi-stakeholder perspective, something that was not found in previous research.

\section{Conclusions and Implications}

The conclusion is that more research is needed in the area of co-creation models between large and small firms, as well as on metrics of the effects from corporate-startup co-creation. The case study of FirstBuild shows that the company use several types of metrics to evaluate the initiative's performance and progression. This data should be included in future research. Lack of research in this area implies that corporations, investing in this kind of efforts with startups, do not actually know if the investment pays off, or not. Further, they can't benchmark their own outcome with other large firms' outcome, investing in a similar co-creation model. For the same reason, startups can't really measure the value for them, e.g. in increased growth rate, and government can't show that invested tax money is giving any real benefits to the local society. To conclude, co-creation between large firms and startups and its effectiveness in regards to different metrics, is currently a big knowledge gap in current research. Much more research is therefore needed in this area.

\section{Endnote}

1. While the first corporate incubator was established in New York in 1959 it was not until later the concept disseminated to Europe in the 1980s. The Corporate accelerator is a rather new phenomenon and the first corporate accelerator was established in 2005 (Bauer et al. 2016).

\section{References}

Alänge, S. and Steiber, A. (2018). Three Operational Models for Ambidexterity in Large Corporations. Triple Helix, 5 (1).

Alänge, S., and Steiber, A. (2019). FirstBuild: Combining the Innovativeness of a Small Startup with a Large Corporation's Strengths. In: Nourani, C.F., ed., Computing 
Predictive Analytics, Business Intelligence, and Economics: Modelling Techniques with Startups and Incubators. Waretown, NJ: Apple Academic Press, pp. 13-36.

Autio, E., Nambisan, S, Thomas, L.D.W., and Wright, M. (2018). Digital Affordances, Spatial Affordances, and the Genesis of Entrepreneurial Ecosystems. Strategic Entrepreneurship Journal, 12 (1), pp. 72-95.

Bauer, S., Obwegeser, N., and Zlatko, A. (2016), Corporate Accelerators: Transferring technology innovations to incumbent companies, MCIS 2016 Proceedings. Paper 57 .

Bendapudi, N., and Leone, R. (2003). Psychological Implications of Customer Participation in Co-Production. Journal of Marketing, 67, pp. 14-28.

Blank, S.G. (2005). The Four Steps to the Epiphany: Successful Strategies for Products that Win. Sussex, WI: Quad/Graphics.

Blank, S.G. (2013). Why the Lean Startup Changes Everything. Harvard Business Review, $91(5)$, pp. $63^{-72 .}$

Chesbrough, H. (2003). Open Innovation: The New Imperative for Creating and Profiting from Technology. Boston, MA: Harvard Business School Press.

Christensen, C.M., and Overdorf, M. (2000). Meeting the Challenge of Disruptive Change. Harvard Business Review, 78 (2), pp. 66-76.

Cohen, Susan G., and Yael V. Hochberg. "Accelerating Startups: The Seed Accelerator Phenomenon." sSRN Journal, March 2014, 1-16. doi:10.2139/ssrn.24180oo.

Drori, I., and Wright, M. (2018). Accelerators: Characteristics, Trends and the New Entrepreneurial Ecosystem. In: Wright and Drori, eds., Accelerators. Successful Venture and Growth. Cheltenham, UK and Northampton, USA: E.E. Elgar pp. 1-20.

Dubois, A., and Gadde, L.E. (2002). Systematic combining: an abductive approach to case research. Journal of Business Research, 55(7), pp. 553-56o.

Enz, M. and Lambert, D. (2012). Using Cross-Functional, Cross-Firm Teams to CoCreate Value: The Role of Financial Measures. Industrial Marketing Management, 41 (3), pp. 495-507.

Fochler, M. (2016). Beyond and Between Academia and Business: How Austrian Biotechnology Researchers Describe High-Tech Startup Companies as Spaces of Knowledge Production. Social Studies of Science, 46 (2), pp. 259-281.

Frow, P., Nenonen, S., Payne, A. and Storbacka, K. (2015), Managing Co-Creation Design: A Strategic Approach to Innovation. British Journal of Management, 26 (3) pp. 463-483. Available at: https://doi.org/10.1111/1467-8551.12087.

Fuller, J., Muhlbacher, H., Matzler, K., and Jawecki, G. (2009). Consumer Empowerment through Internet-Based Co-Creation. Journal of Management Information Systems, 26 (3), pp. 71-122.

Fuller, J (2010). Refining Virtual Co-Creation from a Consumer Perspective. California Management Review, $5^{2}$ (2), pp. 98-122.

Ghosh, S., Hughes, M., Hughes, P. (2017), Developing dynamic transformation capabilities in high velocity environment: A study of Industrial Internet companies. 
Hagel, J., Seely Brown, J., De Maar, A., and Wooll, M. (2018). GE First Build:A Trailblazing Workgroup Builds Community with the Crowd to Speed Innovation. Deloitte Insights, Deloitte Center for the Edge. Available at: https://www2.deloitte.com/insights/us/ en/topics/talent/businessperformance-improvement/GE-FirstBuild.html.

Hatch, M. (2013), The maker movement manifesto: Rules for innovation in the new world of crafters, hackers, and tinkerers, New York: McGraw-Hill.

Hughes, T. (2014). Co-Creation: Moving Towards a Framework for Creating Innovation in the Triple Helix. Prometheus: Critical Studies in Innovation. doi:10.1080/08109028 .2014 .971613 .

Huhtamäki, J., Russell, M.G., Still, K., and Rubens, N. (2011). A Network-Centric Snapshot of Value Co-Creation in Finnish Innovation Financing. Open Source Business Resource. Available at: http://timreview.ca/article/424.

Islam, N., Buxmann, P., and Ding, D. (2017). Fostering Digital Innovation through InterOrganizational Collaboration between Incumbent Firms and Startups. In: Proceedings of the 25th European Conference on Information Systems (ecis), Guimaraes, Portugal, June 5-10, pp. 1029-1043.

Karpen, I., Bove, L., Lukas, B., and Zyphur, M. (2015). Service-Dominant Orientation: Measurement and Impact on Performance Outcomes. Journal of Retailing, 91 (1), pp. 89-108.

Korhonen, H., Still, K., Seppänen, M., Kumpulainen, M., Suominen, H., and Valkokari, K. (2017). The Core Interaction of Platforms: How Startups Connect Users and Producers. Technology Innovation Management Review, 7 (9), pp. 17-29.

Lee, S.M., Olson, D.L., and Trimi, S. (2012). "Co-Innovation: Convergenomics, Collaboration, and Co-Creation for Organizational Values. Management Decision, 50 (5), pp. $817-831$.

Maciuliene, M., and Skarzauskiene, A. (2016). Evaluation of Co-Creation Perspective in Networked Collaboration Platforms. Journal of Business Research, 69 (11), pp. 4826-483o.

March, J.G. (1991). Exploration and Exploitation in Organizational Learning. Organization Science, 2, pp. 71-87.

Markovic, S., and Bagherzadeh, M. (2018). How Does Breadth of External Stakeholder Co-Creation Influence Innovation Performance? Analyzing the Mediating Roles of Knowledge Sharing and Product Innovation. Journal of Business Research, 88, pp. 173-186.

Nishikawa, H., Schreier, M., and Ogawa, S. (2013). User-Generated Versus DesignerGenerated Products: A Performance Assessment at Muji. International Journal of Research in Marketing, 30 (2), pp. 16o-167.

Normann, R. (2001). Reframing Business: When the Map Changes the Landscape. Chichester: John Wiley \& Sons.

Normann, R., and Ramirez, R. (1993). From Value Chain to Value Constellation: Designing Interactive Strategy. Harvard Business Review, 71 (4), pp. 65-77. 
Pei, Z. (2017). Co-Creation Experience: Measurement Development and Influence on Value in Sharing Economy. Doctoral dissertation, University of South Carolina. Available at: https://scholarcommons.sc.edu/etd/4338.

Piller, F., and Ihl, C. (2013). Co-Creation with Customers. In: Sigismund Huff, A., Moslein, K.M., and Reichwald, R., eds., Leading Open Innovation. MIT Press Scholarship Online. doi:10.7551/mitpress/9780262018494.003.0172.

Prahalad, C.K., and Ramaswamy, V. (2000). Co-Opting Customer Competence. Harvard Business Review, 78, pp. 79-87.

Prahalad, C.K., and Ramaswamy, V. (2004). Co-Creation Experiences: The Next Practice in Value Creation. Journal of Interactive Marketing, 18 (3).

Prashantham, S., and Birkinshaw, J. (2008). Dancing with the Gorillas: How Small Companies can Partner Effectively with MNCs. California Management Review, $5^{1}$ (1), pp. 6-23.

Ramaswamy, V. (2009). Leading the Transformation to Co-Creation of Value. Strategy and Leadership, 37 (2), pp. 32-37.

Ramaswamy, V., and Gouillart, F. (2010). The Power of Co-Creation. New York, NY: Free Press.

Ries, E. (2011). The Lean Startup: How Constant Innovation Creates Radically Successful Businesses. New York: Crown Business.

Rise, M.P. (2002). Co-production of Business Assistance in Business Incubators: An Exploratory Study. Journal of Business Venturing, 17 (2), pp. 163-187.

Rogers, E.M. (1995). Diffusion of Innovations. New York: The Free Press.

Rothwell, R., and Dodgson, M. (1991). External Linkages and Innovation in Small and Medium-sized Enterprises. R\&D Management, 21 (2), pp. 125-137.

Steiber, A., and Alänge, S. (2015). Organizational Innovation: Verifying a Comprehensive Model for Catalyzing Organizational Development and Change. Triple Helix, 2 (14), pp. 1-28.

Steiber, A., and Alänge S. (2020). Corporate-Startup Collaboration: Effects on Large Firms' Business Transformation. (forthcoming)

Valkokari, K., Seppänen, M., Mäntylä, M., and Jylhä-Ollila, S. (2017). Orchestrating Innovation Ecosystems: A Qualitative Analysis of Ecosystem Positioning Strategies. Technology Innovation Management Review, 7 (3), pp. 12-24.

Von Hippel, E. (1976). The Dominant Role of Users in the Scientific Instrument Innovation Process. Research Policy, 5, pp. 212-239.

Von Hippel, E. (2005). Democratizing Innovation, Cambridge, MA: MIT Press.

Vargo, S.L., Maglio, P.P., and Akaka, M.A. (20o8). On Value and Value Co-Creation: A Service Systems and Service Logic Perspective. European Management Journal, 26, pp. $145^{-15^{2}}$.

Vesalainen, J., Thorgren, S., and Rossi, T. (2017). Toward Cross-Border Engineering Management: Development and Test of a Practice for Idea Generation in CustomerSupplier DFM Teams. Engineering Management Journal, 29 (4), pp. 278-286. 
Webster, J. and Watson, R. (2002), Analyzing the Past to Prepare for the Future: Writing a Literature Review, MIS Quarterly, Vol. 26, No. 2 (Jun., 2002), pp. xiii-xxiii.

Weiblen, T., and Chesbrough, H.W. (2015). Engaging with Startups to Enhance Corporate Innovation. California Management Review, 57 (2), pp. 66-9o.

Wikström, S. (1996). The Customer as Co-Producer. European Journal of Marketing, 30 (4), pp. 6-19. 